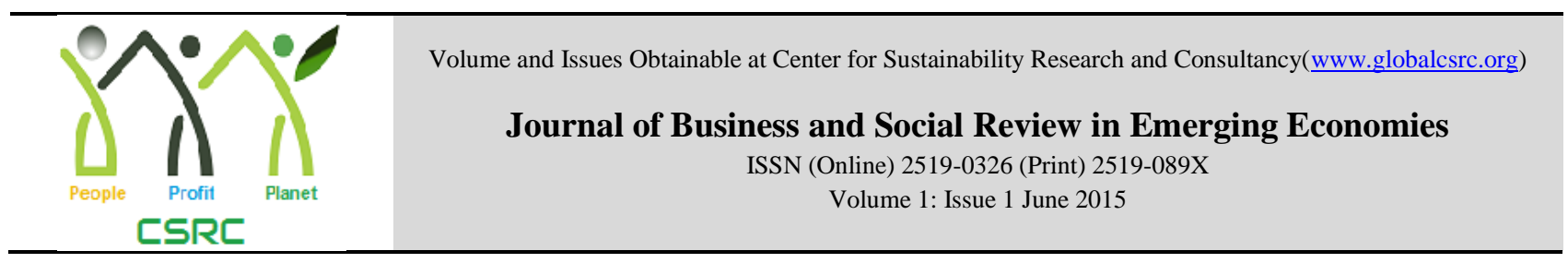

\title{
Pakistani Newspapers on Peace Talks with Tahrik e Taliban Pakistan
}

\author{
${ }^{1}$ Muhammad SohaibSubhani, ${ }^{2}$ Rooh ul Amin Khan, ${ }^{3}$ Dr Khalid Sultan \\ ${ }^{1}$ Department of Media and Communication Studies, International Islamic University Islamabad Pakistan. \\ sohaibsubhani@gmail.com \\ ${ }^{2}$ Asst. Professor, Department of Media and Communication Studies, International Islamic University Pakistan. \\ roohul,amin@iiu.edu.pk \\ ${ }^{3}$ Head of Mass Communication Department, Nizwa College of Applied Sciences, Sultanate of Oman. \\ khalid_sultan.niz@cas.edu.om
}

\begin{tabular}{|c|c|}
\hline ARTICLEDETAILS & ABSTRACT \\
\hline $\begin{array}{l}\text { History } \\
\text { Revised format: May } 2015 \\
\text { AvailableOnline: June } 2015\end{array}$ & $\begin{array}{l}\text { Negotiations between two parties always have newsworthiness. Results of } \\
\text { the negotiations can be strongly influenced by the media coverage. } \\
\text { Pakistan's government was also involved in peace negotiation with Tahrik } \\
\text { e Taliban Pakistan (TTP) during January and February 2014. It was the }\end{array}$ \\
\hline $\begin{array}{l}\text { Keywords } \\
\text { Peace talks, } \\
\text { Tehrik e Taliban Pakistan } \\
\text { (TTP), Agenda Setting, } \\
\text { Editorial Policy, Comparative } \\
\text { analysis. }\end{array}$ & $\begin{array}{l}\text { most discussing issue in Pakistani media at that time. The aim of this } \\
\text { research is to analyze the editorial policy of three Pakistani English } \\
\text { language newspapers; Dawn, Nation and The News to check their } \\
\text { favorable or unfavorable behavior regarding peace talks during January } \\
\text { and February 2014. Agenda setting, priming and farming theories were } \\
\text { used in this study. Qualitative content analysis method was used in this } \\
\text { study to analyze the editorial policy of these three newspapers. Findings }\end{array}$ \\
\hline $\begin{array}{l}\text { JEL Classification: } \\
E 60, E 63, E 69,\end{array}$ & $\begin{array}{l}\text { revealed that all these three newspapers gave significant coverage to the } \\
\text { peace talks issue but Nation gave more coverage to the issue. Findings } \\
\text { also revealed that Dawn and The News, most of the time showed neutral } \\
\text { behavior but tilted towards unfavorable position regarding peace talks. } \\
\text { Nation showed strongly unfavorable behavior regarding peace talks. So it } \\
\text { is concluded that all these three newspapers were mostly against the peace } \\
\text { talks and government and media were not on the same page on the issue } \\
\text { of peace talks. }\end{array}$ \\
\hline
\end{tabular}

(C) 2015 The authors, under a Creative Commons Attribution-

NonCommercial 4.0

\section{Introduction}

After 9/11 and US invasion of Afghanistan, a fraction of Afghan Taliban along with Al Qaida's foreign militants ran away in to the adjacent tribal areas of Pakistan. They were welcomed by the tribe's men due to the traditions and customs of the tribal areas and their common believes and ideologies regarding

*Corresponding author'semail address: sohaibsubhani@gmail.com

Recommended citation:Subhani, M. S., Khan, R. A. and Sultan, K. (2015). Pakistani Newspaper on Peace Talks with Tahrik e Taliban Pakistan.Journal of Business and Social Review in Emerging Economies, 1 (1) 47-60. DOI: https://doi.org/10.26710/jbsee.v1i1.7 
Jihad. They put Pakistan in a conflicting situation and started their extremist activities in the country. The emergence of the Tahrik e Taliban Pakistan (TTP) in 2007 makes the situation more terrible (Siddique, 2014). Meanwhile, government of Pakistan held various negotiation efforts (In April 2004: The Shakai Peace Agreement, In February 2005: The Sararogha Peace Agreement and in May 2008: The Swat Agreement) but all ended unsuccessful (Sheikh\& Greenwood,2013). After the establishment of new PML (N) government in Pakistan in 2013, an all party's conference (APC) was called by the government on $9^{\text {th }}$ September 2013. This APC supported the peace talks with TTP and declared the military operation against those who would not negotiate with the government. On $31^{\text {st }}$ December 2013, PM Nawaz Shareef meet MolanaSamiulhaq and both leaders were agreed on starting peace talks with TTP. During the national assembly's session on $29^{\text {th }}$ January 2014 , PM Nawaz Shareef made a proclamation of starting peace talks with TTP and a new debate about the future of peace talks begins on media (Safi, 2014). In the start of 2014, all types of local and international media were full of stories discussing peace talks in Pakistan. This heavy news coverage of the issue put the government and public in an ambiguous situation. Hussain (2014) quoted Prime Minister Nawaz Shareef and information minister PervaizRasheed to criticize media's role during peace talks. It was a debate among the media researchers as well as policymakers that what should be the role of media during the whole peace process.

This study aims to analyze the coverage of Dawn, Nation and The News on peace talks in their editorials from January $1^{\text {st }} 2014$ to February $28^{\text {th }} 2014$. The purpose of this research is to provide a scientific research that how these newspapers frame the issue of peace talks in consideration with their government's policy on the issue.

\section{Research questions}

1. To what extent Dawn, Nation and The News gave coverage to the issue of peace talks in their editorials?

2. Whether Dawn, Nation and The News supported Pakistan's government policy on peace talks or not?

3. What are the similarities and differences in the editorial coverage of Dawn, Nation and The News on the issue of peace talks?

\section{Literature Review}

Literature review is a planned search and analysis of already published information. It is organized according to the research objectives, and the problem that a researcher wants to address. It helps to point out the direction of research (Cooper, 1998). Media's role during the peace process is an important area of study. Bratic\&Schirch (2007) discussed that media can play a vital role in peace building processes along with some other strategies but it is not suitable in all peace building situations. Media usually do not respect the secrecy and tries to highlight all conflicting angles of the problem to increase their ratings rather than to serve a larger objective. It is also observed that the impact of media on conflict is greater than the impact of media on conflict resolution (Wolfsfeld, 2004). Peace journalism highlights the structural and cultural reasons of conflict and violence instead of creating polarization. It tries to explain the violence and conflict relating to many groups and suggest various objectives. Peace journalism can helps to promote peace initiatives. It can also explain the stated situations and actual situations. (Galtung and Vincent, 1992; Wolfsfeld, 2003; Lynch, 2005; cited in Siraj, 2008).

It is a basic task of the media reporters and their editors to adopt a balance position during conflicts. In such situations, media's interpretation has also been too stimulating than earlier. In Pakistani scenario, there is no concept of Peace journalism. Peace journalism can resolve conflicts and bring peace in the 
country. The news media can take part in any peace process. Primarily, they assist in settings the political landscape in which the peace process occur. Then, the media has a great control on the policy and can access to the stakeholders of the conflict. Third, the media has a large power to build a narrative for peace process. Fourth, the media can reinforce the public authority as the stakeholders involved in the peace process (Jana \& Khan, 2011).

As government is the main stakeholder in the current situation and our aim is to identify the media's role towards government's policy on this issue. It is observed that previously most of the media were tilted towards government's policies due to many reasons. Akhtar (2000) analyzed the newspapers from 1970 to 1990 and argued that legal actions, harassment and most importantly economic dependence on the government are the reasons that forced media to favor the government. The effects of these pressures were scene in 1970's elections, when Awami League had won the majority of the seats but the politicians and military in West Pakistan were against the Awami League. Mainstream print media in West Pakistan supported the military's stance at that time. This influence of the government was same in the regime of Zia ulHaq when content that criticized the president and the government's policies was strictly banned (Niazi, 1994). With the passage of time, Media's dependence on government for advertisement changed. Rafiq (2007) stated that The News and Dawn published maximum anti government editorials during judicial crises in 2007. After that, these newspapers did not give much importance to judicial crises. All these three examples were from the different military regimes. But previous two cases were different from the last one. According to Manzoor (2002) Pakistani press is very much related to the international issues. He further argues that Pakistani press enjoys the freedom and criticizes the government but patriotism is also exists in the Pakistani press. So we can say that harmony among the media and government's opinions is varying from issue to issue and one government to other government.

Theoretical framework is a conceptual model of how a theory makes real sense of the relationship among several themes that are related to the problem (Sekarran,2000).For this study Agenda Setting theory is used, which describes that media sets the agenda and highlights any specific issue. Agenda setting is the concept that the news media decides the issues that the people thinks are important by selection of some specific news (Tankard et. al. 1992). Cohen (1963) also gave the idea of agenda setting. He stated about the power of the press that it may not be successful much of the time in telling people what to think, but it is successful in telling people what to think about. According to researchers Mc. Combs and Shaw (1972), audience not only learns about public issue and other matters through media but they also learn about how much importance should give to a specific issue by the emphasis that mass media place upon that issue.

Priming of any issue on media also matters in its importance among masses. The amount of time and space that is given to an issue by media makes the audience interested and attentive towards that particular issue. Similarly, audience perception about events is influenced by historical background with which they are familiar with by their own experience or by media. Media reporting has very strong effects as it is almost impossible for audiences to ignore the events such as the Olympics or World Cup. Such reporting makes the people interested in these activities for the time being. Though many of the people were not sports fans before the reporting of these events but the people got trapped in the instant (Shanto, Mark \& Donald, 1982).

Collecting, editing and presenting information in the news is a difficult job on the part of media reporter. A reporter is also a human being and he or she cannot be a neutral because it is also part of a culture. Partiality and bias cannot completely erase. The journalists ask the questions, receive the information and refine it according to their own frames. Journalist framing may change or adjust the opinion of the people. Stephen (2001) cited Entman (1993) that "A frame is identified by its result or effect. The 
frames selected according to some aspects of a reality and make those aspects more prominent, in such a way as to promote a particular problem and causal explanation." Stephen further cited Tankard (1991) that "A frame is a central idea of news content that gives a context and suggests what the main issue is through the selection, removal, highlighting, and explanation of specific ideas".

\section{Methodology}

Hall (1975) has suggested that both qualitative and quantitative methodologies of content analysis should use to eliminate the weaknesses of content analysis. For this study the triangulation method is used that is both the qualitative and quantitative techniques are used.

All related editorials of these three newspapers from January $1^{\text {st }} 2014$ to February $28^{\text {th }} 2014$ were selected as universe. It was the peak time of this issue on Pakistani media. There is no specific sampling technique used in this study and all related editorials were taken as sample. A whole editorial is considered as unit of analysis.

Prominence, which is given to the issue of peace talks by all these three newspapers in their editorials, determined by three different ways. Firstly total number of related editorials of Dawn, Nation and The News were compared by total number of all editorials published in these newspapers during two months January and February 2014. Secondly all related editorials were divided into editorials and editorial notes to check the placement. The newspaper which gave more editorials than editorial notes was considered to give more prominence to the issue. Thirdly total numbers of words published in all related editorials of a specific newspaper were counted and got average number of words published by that specific newspaper in related editorials.

To identify the nature of the coverage, data was divided into coding categories. Coding categories are the topics which are related to a main theme. Following topics identified as coding categories after reading these three newspapers during January and February 2014.
A. Negotiations
B. Terrorist attacks
C. Government
D. TTP
E. Negotiators
F. Military operation
G. Cease fire

To find out the direction of the editorials, data was examined according to three point scale: Favorable (+), Unfavorable (-) and Neutral or balanced (0). The editorial which discussed the Government, TTP and Negotiators in negative way, considered as unfavorable towards peace talks and vice versa. The editorial which clearly put the blame of terrorist attack on TTP and used it as a reason to stop peace talks, considered as unfavorable towards peace talks and vice versa. The editorial which is in the favor of military operation and against the cease fire, considered as unfavorable towards peace talks and vice versa. The editorials which discussed all these topics in a balance way considered as neutral.

For the qualitative analysis, the researcher analyzed the headings and wordings of related editorials of these three newspapers. The researcher has tested the coding sheets and coding categories and check inter coder reliability which is 0.9 , before starting study and made minor changes in coding sheets for final study.

\section{Results}

Total 71 editorial were analyzed in this study among 17 editorials of Dawn, 20 of The News and 34 editorial of Nation included.

\section{Priming Test}

Figure 1 and 2shows that researcher read total 489 editorials of Dawn, The News and Nation during 
January and February 2014 and found 71 editorials related to the peace talk issue. During two months total 177 editorials were published in Dawn, in which 17(9.6\%) editorials were related, 139 editorials were published in The News, in which 20(14.39\%) editorials were related and 173 editorials were published in Nation, in which 34(19.65\%) editorials were related to the issue.

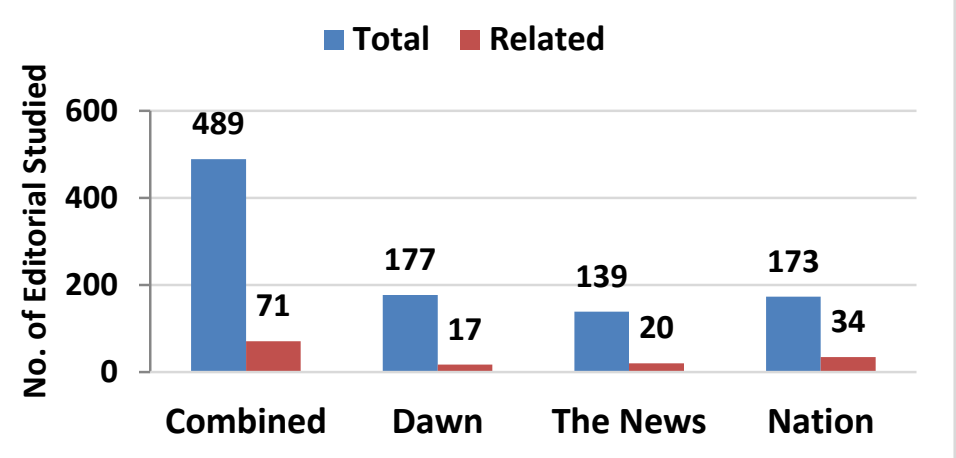

Fig. 1: Number of editorials studies from three newspapers during January and February, 2014.

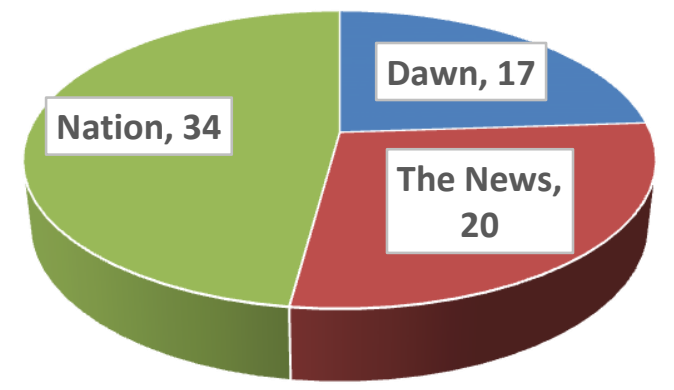

Fig. 2: Number of related editorials published in three newspapers during January and February, 2014.

Figure 3 and 4 illustrate the division between editorials and editorial notes of each newspaper Dawn, The News and Nation during January and February 2014. Dawn published 14 editorials and 3 editorial notes, The News published 13 editorials and 7 editorial notes and Nation published 31 editorials and 3 editorial notes related to peace talks during January and February 2014.

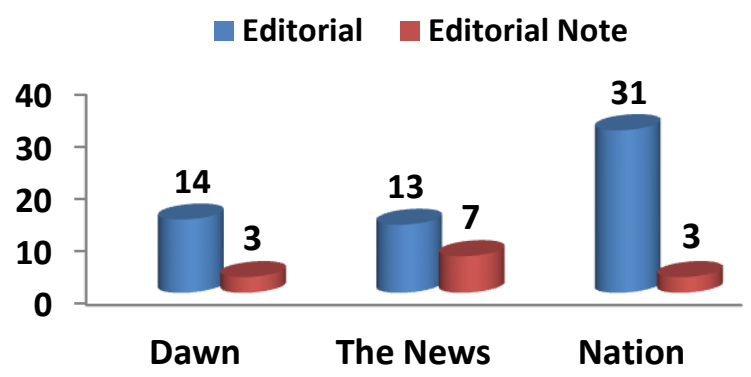

Fig. 3: Division in terms of number between related editorials and editorial notes published in three newspapers during January and February, 2014. 


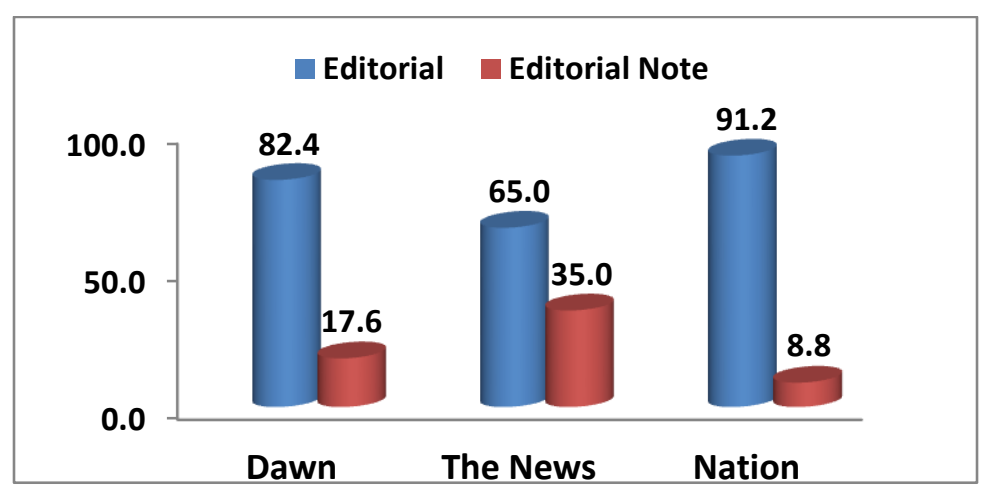

Fig. 4: Division in terms of percentage between related editorials and editorial notes published in three newspapers during January and February, 2014.

Figure 5 illustrate the minimum, maximum and average number of words published in all related editorials of Dawn, The News and Nation during January and February 2014. Dawn devoted total 7514 words in related editorials with 321 minimum, 477 maximum and 442 average numbers of words. The News devoted 9191 words in related editorials with 297 minimum, 656 maximum and 460 average numbers of words. Nation devoted 15131words in related editorials with 288 minimum, 621 maximum and 445 averages numbers of words. Table 1 also explains the same as figure 5.

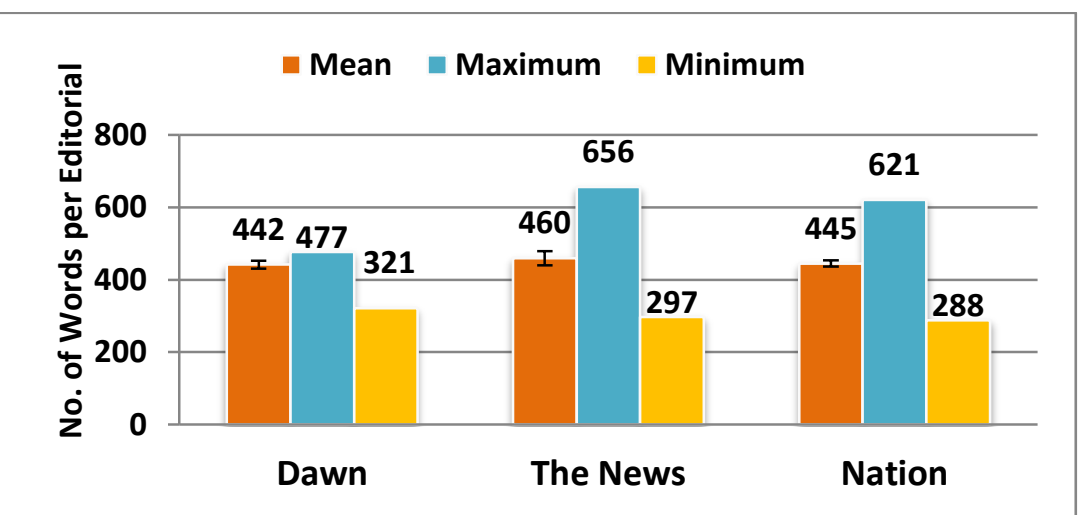

Fig. 5: Number of words published in related editorials in three newspapers during January and February, 2014.

Table 1: Statistical analysis of number of words published in related editorials in three newspapers during January and February, 2014.

\begin{tabular}{|l|l|l|l|l|l|l|l|l|}
\hline Variable & Mean & Minimum & Maximum & SD & $\begin{array}{l}\text { SE } \\
\text { (Mean) }\end{array}$ & DF & $\mathbf{T}_{(\text {cal })}$ & $\mathbf{P}$ \\
\hline Dawn & 442.00 & 321 & 477 & 45.44 & 11.020 & 16 & 40.11 & 0.000 \\
\hline The News & 459.55 & 297 & 656 & 85.81 & 19.187 & 19 & 23.95 & 0.000 \\
\hline Nation & 445.03 & 288 & 621 & 52.12 & 8.938 & 33 & 49.79 & 0.000 \\
\hline
\end{tabular}

\section{Framing Test}

Following figures illustrate the direction of editorials published in Dawn, The News and Nation during January and February 2014 in different category.

Figure 6 explains the comparative direction of editorials of Dawn, The News and Nation regarding category A (Negotiations) during January and February 2014. Figure reflects that Dawn was $0.00 \%$ pro, $0.00 \%$ anti and remains $23.5 \%$ neutral towards category ' $A$ '. The News was $0.00 \%$ pro, $5.00 \%$ anti and 
remains $5.00 \%$ neutral towards category ' $\mathrm{A}$ '. Nation was $0.00 \%$ pro, $23.5 \%$ anti and remains $0.00 \%$ neutral towards category 'A'.

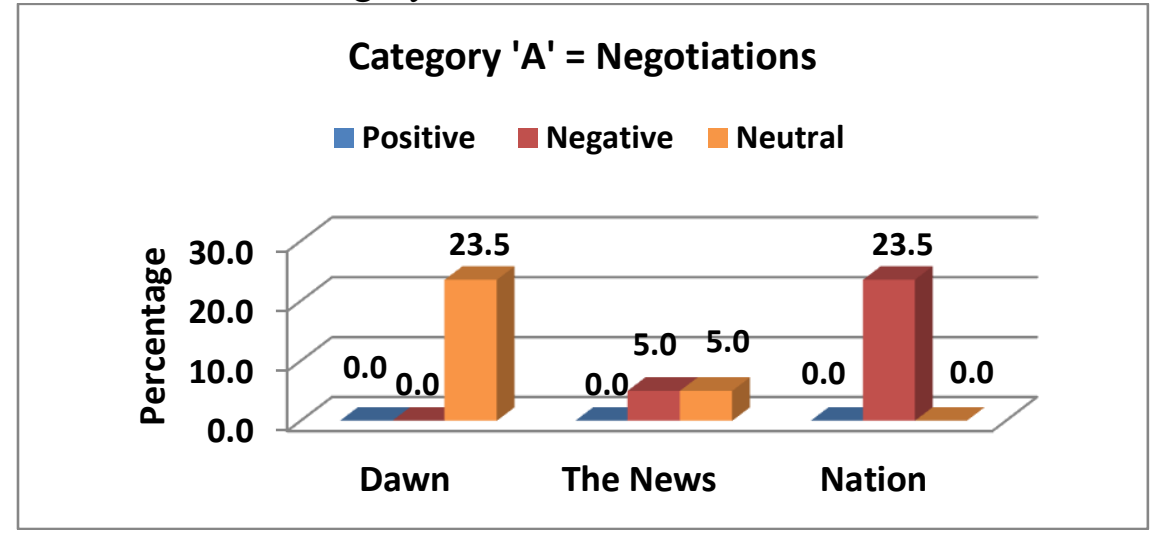

Fig. 6: Direction of editorials towards Category ' $\mathbf{A}$ ' published in three newspapers during January and February, 2014.

Figure 7 explains the comparative direction of editorials of Dawn, The News and Nation regarding category B (Terrorist Attacks) during January and February 2014. Figure reflects that Dawn was $0.00 \%$ pro, $5.9 \%$ anti and remains $11.8 \%$ neutral towards category ' $\mathrm{B}$ '. The News was $5.00 \%$ pro, $15.0 \%$ anti and remains $10.0 \%$ neutral towards category ' $\mathrm{B}$ '. Nation was $0.00 \%$ pro, $8.8 \%$ anti and remains $0.00 \%$ neutral towards category 'B'.

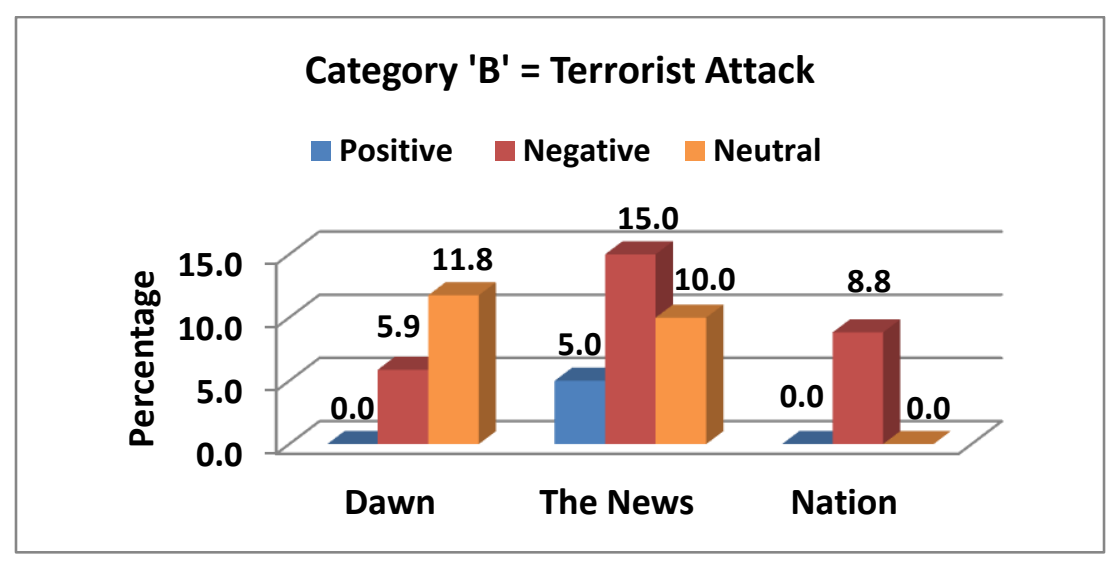

Fig. 7: Direction of editorials towards Category 'B' published in three newspapers during January and February, 2014.

Figure 8 explains the comparative direction of editorials of Dawn, The News and Nation regarding category C (Government) during January and February 2014. Figure reflects that Dawn was $0.00 \%$ pro, $11.8 \%$ anti and remains $5.9 \%$ neutral towards category ' $\mathrm{C}$ '. The News was $0.00 \%$ pro, $5.00 \%$ anti and remains $10.0 \%$ neutral towards category ' $\mathrm{C}$ '. Nation was $0.00 \%$ pro, $11.8 \%$ anti and remains $2.9 \%$ neutral towards category ' $\mathrm{C}$ '. 


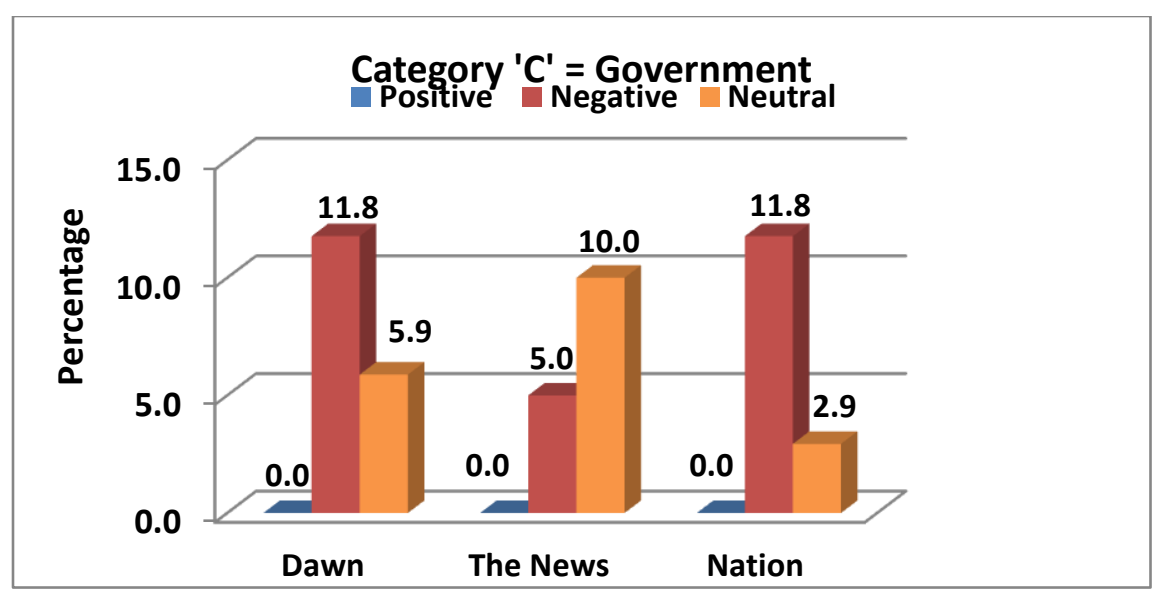

Fig. 8: Direction of editorials towards Category ' $C$ ' published in three newspapers during January and February, 2014.

Figure 9 explains the comparative direction of editorials of Dawn, The News and Nation regarding category D (TTP) during January and February 2014. Figure reflects that Dawn was $0.00 \%$ pro, $11.8 \%$ anti and remains $0.00 \%$ neutral towards category ' $D$ '. The News was $0.00 \%$ pro, $5.00 \%$ anti and remains $5.00 \%$ neutral towards category ' $D$ '. Nation was $0.00 \%$ pro, $14.7 \%$ anti and remains $0.00 \%$ neutral towards category ' $\mathrm{D}$ '.

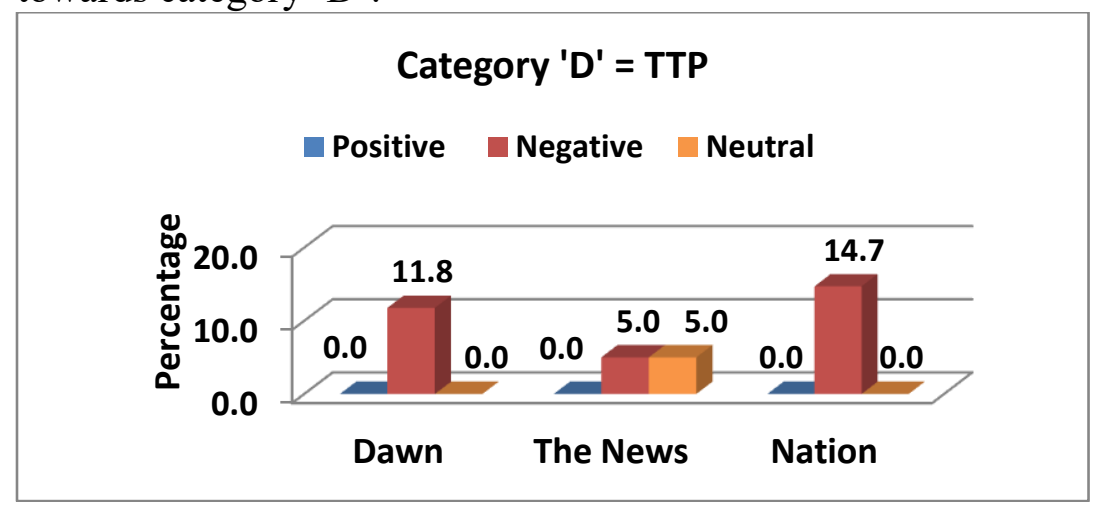

Fig. 9: Direction of editorials towards Category 'D' published in three newspapers during January and February, 2014.

Figure 10 explains the comparative direction of editorials of Dawn, The News and Nation regarding category E (Negotiators) during January and February 2014. Figure reflects that Dawn was 5.9\% pro, $0.00 \%$ anti and remains $5.9 \%$ neutral towards category ' $E$ '. The News was $0.00 \%$ pro, $10.0 \%$ anti and remains $10.0 \%$ neutral towards category ' $E$ '. Nation was $0.00 \%$ pro, $5.9 \%$ anti and remains $5.9 \%$ neutral towards category ' $E$ '. 


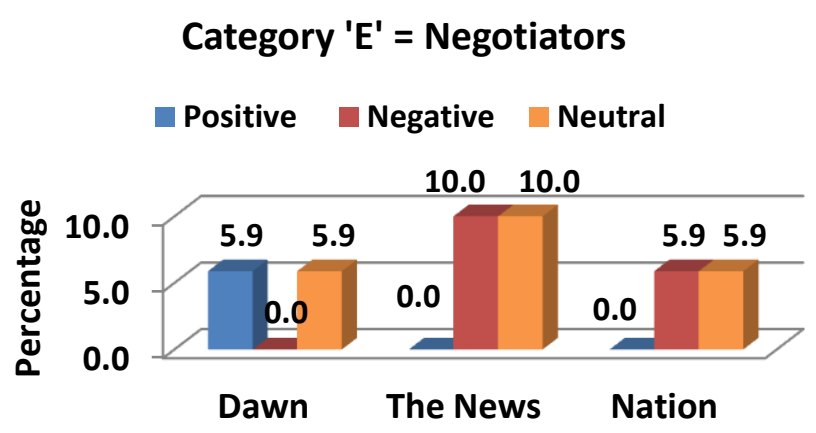

Fig. 10: Direction of editorials towards Category ' $\mathbf{E}$ ' published in three newspapers during January and February, 2014.

Figure 11 explains the comparative direction of editorials of Dawn, The News and Nation regarding category F (Military Operation) during January and February 2014. Figure reflects that Dawn was $0.00 \%$ pro, $0.00 \%$ anti and remains $11.8 \%$ neutral towards category ' $F$ '. The News was $0.00 \%$ pro, $0.00 \%$ anti and remains $10.0 \%$ neutral towards category ' $F$ '. Nation was $0.00 \%$ pro, $20.6 \%$ anti and remains $0.00 \%$ neutral towards category ' $\mathrm{F}$ '.

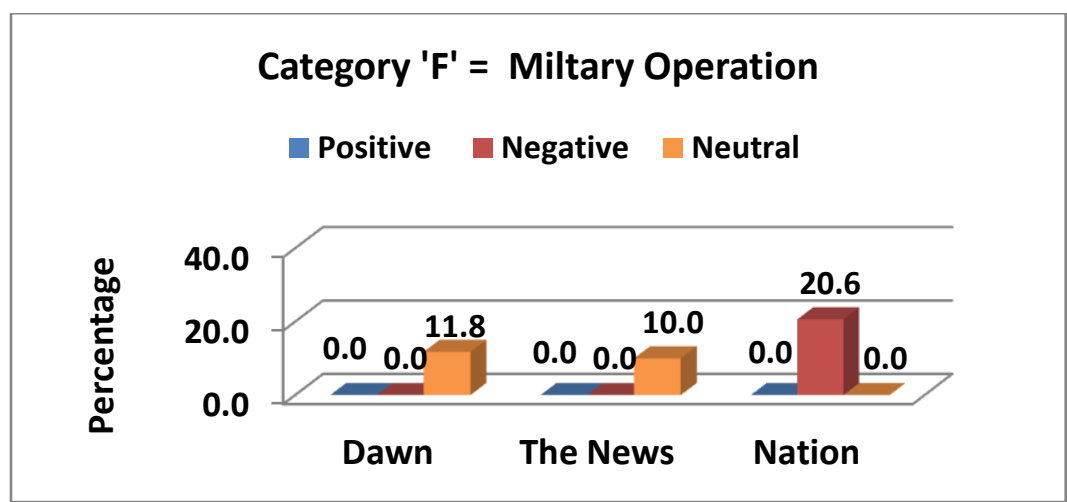

Fig. 11: Direction of editorials towards Category ' $\mathbf{F}$ ' published in three newspapers during January and February, 2014.

Figure 12 explains the comparative direction of editorials of Dawn, The News and Nation regarding category G (Cease Fire) during January and February 2014. Figure reflects that Dawn was $0.00 \%$ pro, $0.00 \%$ anti and remains $5.9 \%$ neutral towards category ' $G$ '. The News was $0.00 \%$ pro, $5.00 \%$ anti and remains $0.00 \%$ neutral towards category ' $\mathrm{G}$ '. Nation was $0.00 \%$ pro, $5.9 \%$ anti and remains $0.00 \%$ neutral towards category ' $\mathrm{G}$ '.

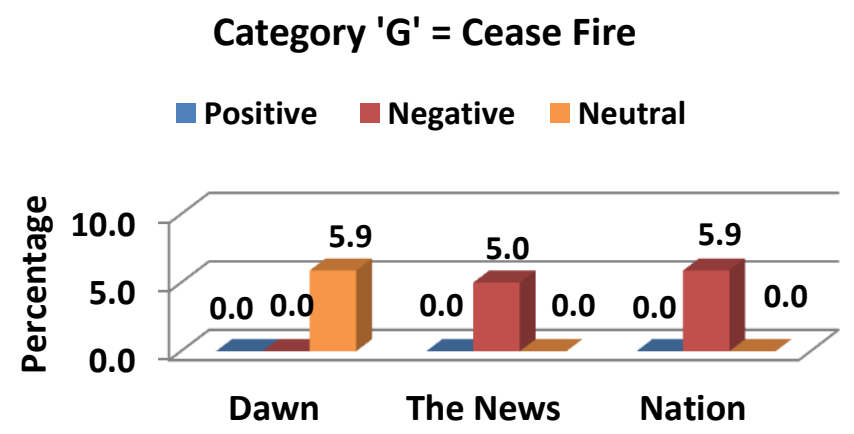

Fig. 12: Direction of editorials towards Category ' $G$ ' published in three newspapers during January and February, 2014. 
Figure 13 explains the overall direction of editorials of Dawn, The News and Nation during January and February 2014. Figure reflects that Dawn was $5.9 \%$ pro, $29.4 \%$ anti and remains $64.7 \%$ neutral towards peace talks. The News was $5.00 \%$ pro, $45.0 \%$ anti and remains $50.0 \%$ neutral towards peace talks. Nation was $0.00 \%$ pro, $91.2 \%$ anti and remains $8.8 \%$ neutral towards peace talks. Table 2 reflects the number of editorials along with percentage.

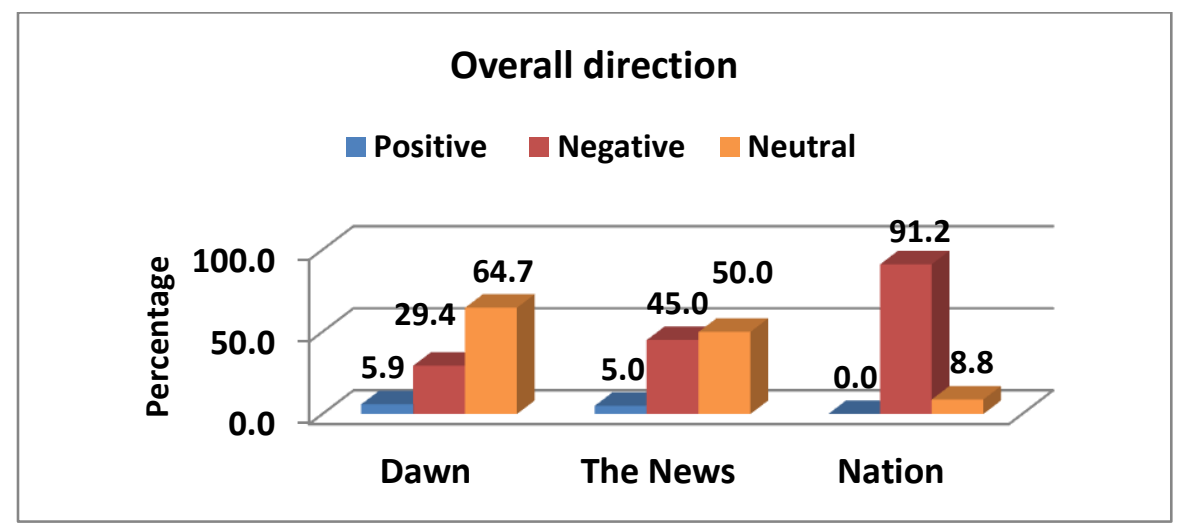

Fig. 13: Overall Direction of editorials published in three newspapers during January and February, 2014.

Table 2: Overall Direction of editorials published in three newspapers during January and February, 2014.

\begin{tabular}{|l|l|l|l|l|l|}
\hline Newspapers & $\begin{array}{l}\text { Studied } \\
\text { Editorial }\end{array}$ & $\begin{array}{l}\text { Related } \\
\text { Editorial }\end{array}$ & Positive & Negative & Neutral \\
\hline Dawn & 177 & 17 & $1(5.9 \%)$ & $5(29.4 \%)$ & $11(64.7 \%)$ \\
\hline The News & 139 & 20 & $1(5.0 \%)$ & $9(45.0 \%)$ & $10(50.0 \%)$ \\
\hline Nation & 173 & 34 & $0(0.0 \%)$ & $31(91.2 \%)$ & $3(8.8 \%)$ \\
\hline
\end{tabular}

\section{Discussion}

For this study the triangulation method is used and qualitative data also consider besides quantitative technique. Following is the discussion on qualitative data. Findings show that all these three newspapers had unfavorable stance towards peace talks. They did not support any chance for negotiations between TTP and Government of Pakistan. They were very clear that the government must not consider any peace talks.

\section{Treatment of the Editorials of Dawn}

Findings reveal that Dawn remains mostly neutral towards the peace talks but tilted towards negative side. Following are some headings of the editorials of Dawn; The wrong choice, No policy to fight militancy, Military operation is needed, More killings by Taliban etc. All these headings show a clear stance of Dawn against peace talks.

Dawn published an editorial on January $2^{\text {nd }} 2014$ named "The wrong choice" and argues;

"A pattern seems to be developing in the government so called strategy against militancy. PM, after meetings with security officials stated that the resolve to defend the country by whatever means, militarily too is reiterated. While after meetings with political allies, the preference for talks is reinforced. Prime Minister Nawaz Sharif appeared to have authorized SamiulHaq, the so called godfather of the Afghan Taliban, to reach out to the TTP and set the stage for dialogue".

The editorial shows the government's confusion on the peace talk issue and high lights the civil military 
divide on the issue. There is a strong satire can also be seen on SamiulHaq, who was considering for initiating the negotiations. The editorial called him the godfather of the Afghan Taliban. Though editorial accepts that his task is to contact to the TTP and set the stage for dialogue, but at the same time, making him controversial.

Dawn published an editorial on February $2^{\text {nd }} 2014$ named "The new TTP" stated;

"While the focus in recent days has been on the many rounds of talks and why they failed, there is another essential aspect that has been somewhat overlooked, the TTP of 2014 is nothing like the Nek Mohammad-led group of predominantly Mehsud militants in 2004. Even now, with the government once again offering dialogue on unspecified terms and seemingly no red lines, the TTP has shown its shrewdness by conditionally accepting the dialogue".

The editorial is trying to portray the whole dialogue in a complex way. Benjamin Netanyahu's quote about negotiations better explain this situation. "You can't end negotiations unless you begin them and you can't begin them if you continually negotiate about the terms to begin negotiations". No red lines can be drawn before and during negotiations. It can only be possible after the completion of dialogue.

\section{Treatment of the Editorials of The News}

Findings reveal that The News also remains mostly neutral towards peace talks but published more negative editorials towards peace talks than Dawn. Following are some headings of the editorials of The News; Action or what? How not to fight, or talk to, terror, The language of violence, We need answers, Talking to the TTP etc. The language of the headings is a bit neutral than Dawn.

The News published an editorial on January 1 st 2014 named "Stepping forward" stated;

"At a one-on-one meeting with the prime minister in Islamabad, Maulana Sami was assigned the task of moving ahead with the talk process with the Taliban. How significant they will prove to be only time will tell, with the man chosen as mediator going into what will be an hugely significant dialogue attempt with the backing of both the civilian and military setup".

In another editorial published on January $23^{\text {rd }} 2014$ named "Action or what" argue;

"The military has claimed it will support whatever course the government charts but there have been murmurs that it opposes talks. Could the action in North Waziristan be a way of boxing the prime minister into a corner"?

These editorials also highlighting the issue of civil military divide. As we have seen the same scenario in Dawn's editorials, civil military divide was the most discussing argument during the whole peace talks process, presenting in print media as well as in electronic media.

In the following editorials, The News presents the case of negotiations in a bit neutral way. The News published an editorial on February $6^{\text {th }} 2014$ named "Talk and terror" argue;

"Taking the TTP at its word is always a dicey proposition even though they are usually first to take credit for attacks. At the same time, blaming them for the attacks without any proof could lead to negotiations being scuttled before they have even begun. These attacks leave the government in a difficult position. A strong possibility exists that the attacks were carried out by a faction within the TTP but without authorization from the leadership".

In another editorial published on February $22^{\text {nd }} 2014$ named "Now is the time" argue;

"Tactically; it would make sense to allow the negotiating teams to continue their talks. Even if a breakthrough is not expected, there is surely no harm in keeping the avenues of communication open. We should have no illusions that the fight will be anything other than tough and brutal".

\section{Treatment of the Editorials of Nation}

The case of Nation was very much different in its editorial coverage from other two newspapers. Nation remains strongly unfavorable towards peace talks and published very few neutral editorials towards peace talks. Nation showed strongly negative attitude towards peace talks and use the statement like "Say no to talks", "Here we go again. Once again, when the public is clamoring for action by the state", 
"There should be no doubt that this peace talks balloon will burst soon enough", "the TTP are not to be trusted, nor can they be negotiated with", "All this is absolute nonsense". Nation argued in one of its editorial published on February $4^{\text {th }} 2014$ named "Committed to committees" "The only productive thing that may come out of this bizarre repeat episode is that it will silence those who claim 'peace has never been given a chance". Following are some headings of editorials of Nation; A self-destructive agenda, Hands up and eyes closed, No more talks, Welcome to the circus, Comedy of terror, Talking into a trap, 15 ways to say no, A flawed ceasefire, An unbelievable ceasefire, How (not) to negotiate etc.

Nation published an editorial on January $2^{\text {nd }} 2014$ named "A self-destructive agenda" and stated;

"The PM must remember that his government is primarily responsible for protecting the lives of the people of this country. By mindlessly insisting on a flawed 'strategy', it is miserably failing in the performance of its basic duty, which means, pack up and go home. The TTP refuses to accept the constitution along with the entire system through which a modern state functions. Its links with the Afghan intelligence are an established fact. If one goes through Mr. Sami-ul-Haq's statements over the last few months, it becomes pretty clear that the middleman is not so much in the middle, rather inclined towards the other side".

This single editorial covers multiple issues regarding peace talks. This portrayed the negotiation between the government and TTP not as a win-win situation but as a negotiation which would have 'compromised government's credibility, locally and internationally. This editorial is trying to giving two different narratives. First is the TTP is not accepting the constitution of Pakistan. It was also the most discussing argument in the debates on print media as well as on electronic media. The other is revealing TTP's links with Afghan intelligence which is relatively a less discussing issue on mass media. As other two newspapers, Nation was also disgracing the middleman.

Nation published an editorial on January $20^{\text {th }} 2014$ named "No more talks" stated;

"Doing nothing is an option - and it's the wrong one. Say no to talks. The participants would be the TTP on one side and some government picked mullahs on the other side are incapable of making any negotiations on behalf of the state and not the fit persons for the job either. Say no to talks. And pick up arms, instead. It would be a decision still ten years too late, but do it now, and perhaps we can redeem our future. Do nothing, and effectively hand over control to the TTP".

The editorial is not only criticizing the negotiators but clearly demanding the military operation against TTP.

Nation published an editorial on February $2^{\text {nd }} 2014$ named "Clear red lines" argue;

"We cannot tell for certain whether the decision to give peace yet another chance was due to the lack of consensus in the Parliament or lack of clarity and confidence on the part of the PM, or perhaps both of these factors. But, there is no doubt over the fact that it was the wrong decision, and time will only further endorse this view".

The editorial is clearly against the negotiations and blaming the parliament and prime minister for this wrong decision of negotiations.

\section{Conclusion}

The objective of the research was to examine the editorial policy of three Pakistani English newspapers Dawn, The News and Nation towards peace talks. Whether they favored the government' policy or not? How much coverage did these newspapers gave to peace talks during January and February 2014? And what were the similarities and differences between these three English language newspapers on the peace talk issue? Editorials show the opinion and policy of a newspaper organization. Editorials are the articles that not only provide information but also explain various issues from an objective point of view. Editorials are considered to be the views of the newspaper organization. These views are prejudiced by a number of factors. They are also influenced by the owner and editorial boards of the 
specific newspapers. Influential personalities can also use their influence to publish their ideological views and agendas. Findings revealed that all these three newspapers gave significant coverage to the issue of peace talks but Nation gave more coverage than others. Findings also revealed that Dawn and The News, most of the time showed neutral behavior but tilted towards unfavorable regarding peace talks. Nation showed strongly unfavorable behavior regarding peace talks. So it is concluded that all these three newspapers were mostly against the peace talks. Findings of the research also clearly reveal that, in current scenario, media and government were not on the same page and under study newspapers gave more space in their editorials to explain "government is confuse in its objectives regarding peace talks. Military and government are not on the same page on peace talks issue and these peace talks are not according to the constitution of Pakistan. These peace talks would never reach to reconciliation or a ceasefire and a military operation upon TTP is necessary to restore the peace and harmony". Finally, government of Pakistan started “Operation Zarb-e-Azb" against TTP's militants in FATA on $15^{\text {th }}$ June 2014. According to above findings, it cannot be say that there was any direct relationship between the coverage of these three newspapers towards peace talks and the decision of the policy makers to take an army action against the TTP in FATA, but it is proposed that the coverage of these newspapers can influence on the policy makers to take such decisions.

\section{References}

Akhtar, Rai S. Media, Religion and Politics in Pakistan. Karachi: Oxford UP, 2000.

Bratic, Vladimir \&Schirch, Lisa.(2007). Why and When to Use the Media for Conflict Prevention and Peace building. European Centre for Conflict Prevention. Retrieved from https://www.sfcg.org/articles/media_for_conflict_prevention.pdf

Cohen, Bernard. C. (1963).The Press and Foreign Policy Princeton, N. J: Princeton UniversityPress.

Copper, H. (1998).Synthesizing Research. A guide for literature reviews.

Hall, S. (1975). Introduction. In A.C.H. Smith et al. (eds.), Paper Voices: The popularpress and social change, 1935-1965.

Hussain, Tallat. (Anchor). (2014 Feb. 2) Live WithTallat [TV broadcast]. Islamabad: Aaj news; Watch on http://www.affairs.com.pk/Play_Show_Live-With-Talat--14th-February-2014_51680

Jan,Mirza \& Khan,Muhammad Rashid. (2011) Peace Journalism and Conflict Reporting: The Case of Pakistani Media,A Research Journal of South Asian Studies Vol. 26, No. 2, July - December 2011, 311-324

Manzoor, U. (2002). Editorial Coverage of Pakistan stand during Pak-India war tension (2001-2002) in Dawn and Nawa $i$ Waqt (Unpublished M. Phil thesis) University of the Punjab, Lahore

McCombs, M. E., \& Shaw, D. L. (1972).The agenda-setting function of mass media. Public Opinion Quarterly36:176-187.

Niazi, Zamir. The Web of Censorship. Karachi: Oxford UP, 1994.

Rafiq, A. (2007). A comparative analysis of editorial coverage regarding judicial crises. Un published master's thesis, Punjab University, Lahore.

Safi, Salem. (Anchor). (2014 Feb. 8). Jirgah. [TV broadcast]. Islamabad: Geo News; Watch on http://www.affairs.com.pk/Play_Show_Jirga--8th-February-2014_51310

Sekaran, U. (2000). Research methods for business. New York: John Wiley \& Sons. Inc.

Shanto, Iyengar. Mark, Peters. \& Donald, Kinder. (1982). Retrieved from http://faculty.buffalostate.edu/smithrd/PR/Framing.htm

Sheikh, Mona K., \& Greenwood, Maja T. J. (2013).Taliban Talks: past, present and prospects for the US, Afghanistan and Pakistan. DIIS. Report. Retrieved from http://reliefweb.int/sites/reliefweb.int/files/resources/RP2013-06-Taliban-Talks_web.pdf

Siddique, Qandeel. (2010). Tehrik-e-Taliban Pakistan: An attempt to deconstruct the umbrella organization and the reasons for its growth in Pakistan's North-West. DIIS.Report. Retrieved 
from $\quad$ http://subweb.diis.dk/graphics/Publications/Reports2010/RP2010-12-Tehrik-eTaliban_web.pdf

Siraj, Syed Abdul. (2008, spring). War or Peace Journalism in Elite US Newspapers: Exploring News Framing in Pakistan - India Conflict. Strategic Studies, XXVIII (1). Islamabad: The Institute of Strategic Studies.

Stephen, D.R. (2001). Prologue-Framing public life. A bridging model for media research. Retrieved from https://docs.google.com/viewer?a=vandq=c ache.

Tankard, J.W \&Servin, W.J. (1992). Communication Theories: Origins Methods and Uses in Mass Communication, Longman publishing company, New York

Wolfsfeld, G. (2004) Media and the path to peace. New York: Cambridge University Press

Retrieved from www.wilsoncenter.org/subsites/ccpdc/pubs/media/medfr.htm 